\title{
TRIM24/RET Fusion Protein
}

National Cancer Institute

\section{Source}

National Cancer Institute. TRIM24/RET Fusion Protein. NCI Thesaurus. Code C99851.

A fusion protein encoded by the TRIM24/RET fusion gene. This protein is comprised of $476 \mathrm{~N}$-terminal amino acids of the transcription intermediary factor 1-alpha protein, including the RING finger, B-box, and coiled-coil domains, fused with most of the Cterminal cytoplasmic domain of the proto-oncogene tyrosine-protein kinase receptor Ret protein, including the tyrosine kinase domain. 